\title{
Research on the Impact of the "Belt and Road" Strategy on China's International Trade Strategy under the Background of Trade Friction
}

\author{
Shuiyan Yan \\ Zhejiang Industry Polytechnic College, Ddepartment: Department of Business and Trade, Zhejiang \\ Shaoxing 312000, China
}

Keywords: Trade war, Trade friction, Belt and Road, Strategic planning, International trade

\begin{abstract}
Since 2007, the overall economic development of the world has shown a slowdown, but the manufacturing industry has basically maintained steady development, which has also led to an increase in the total amount of international investment and trade. China's social and economic development has gradually changed from a growth phase to a quality phase. The "Belt and Road" Initiative is not an economic entity or a political and economic organization, but a strategic vision that China has put forward for cooperation and development. Eliminating trade barriers and achieving trade intercommunication is one of the important elements of the "Belt and Road" strategy. For a long time, the United States has been China's second largest partner. The two countries have strong economic complementarities, close trade relations, and trade frictions are becoming more frequent. Under the conditions of the "Belt and Road", China-US trade will face another friction. How to solve such trade friction is the focus of inquiry.
\end{abstract}

\section{Introduction}

With the determination and comprehensive promotion of the national "Belt and Road" strategy, China's foreign trade has entered a new stage. Chinese enterprises have begun to participate more frequently and deeply in the "Belt and Road" strategy, which will definitely affect China's foreign trade pattern. At the same time, the impact of foreign trade on China's economic and social development will also increase. However, in the process of China's foreign trade development and growth, China's foreign trade enterprises face frequent trade frictions. This has seriously affected the development of China's foreign trade, and effectively preventing trade friction is of great significance to China's foreign trade development.

The comprehensive promotion of the reform of the side structure system has improved the level of creativity in China and highlighted the positive role of regulatory policies in the development of China's industrial development. Under the circumstance of the continuous improvement of China's foreign trade system and the gradual improvement of domestic development trend, China's foreign trade has gradually developed towards high quality, high level, optimized structure, high efficiency 
and rapid growth. At present, according to preliminary estimates, by 2018, China will fully enter a well-off society and gradually move towards a new path of socialist modernization. We will thoroughly implement the spiritual outline of the 19th National Congress and actively develop new socialist concepts and concepts. Promote the development of the "One Belt, One Road" strategy, comprehensively improve cooperation with various countries in the world, and continuously enrich the industrial chain of Chinese enterprises, in order to continuously improve the service quality and product quality of China's trade, and gradually achieve integration with the international level.

In the past 30 years since the reform and opening up, China's foreign trade economic situation has undergone a major transformation. Some domestic industries have overcapacity and the dependence on resources is rising. Nowadays, the original development model has not adapted to the current social and economic development of China. With the development of China's economy, the improvement of science and technology and the current international status in the world, the development of social economy has taken on a new situation: high-level "introduction" and large-scale "going out" to develop together. At present, China's economy is highly correlated with the world economy. China will consistently implement the basic national policy of opening to the outside world and build a new pattern of all-round opening. At the same time, the world today is undergoing complex and profound changes. The deep-seated impact of the international financial crisis continues to emerge, the world economy is recovering slowly, the international investment and trade pattern and the multilateral investment and trade rules are brewing profoundly, and the development problems facing countries are still grim. The "Belt and Road" conforms to the development of economic globalization, and adheres to the spirit of regional cooperation in cooperation to promote the coordinated development of economic policies among countries along the route.

The "Belt and Road" relies on the Eurasian Continental Bridge and the maritime channel. Most of the countries along the route are emerging developing countries and economies, covering Central Asia, North Africa, South Asia, Southeast Asia, the Americas and Central and Eastern Europe. In 2016, the GDP of the Belt and Road countries accounted for about $16 \%$ of global GDP, and the population accounted for about $43.4 \%$ of the global population. Most of these countries have strong economic complementarities with China, and they have deepened the need for deepening trade and economic relations in foreign investment, free trade zone construction, expansion of overseas markets, expansion of energy resource imports, and capacity cooperation. At present, the construction of infrastructure such as roads, bridges, ports, airports and communications in most countries on the "Belt and Road" is seriously inadequate, which restricts the economic development of the region to a certain extent, and China has formed a complete industrial chain in infrastructure equipment manufacturing. Relevant steel, cement, electrolytic aluminum and other industries are also facing the pressure of overcapacity and structural adjustment. Therefore, by improving the infrastructure level of countries along the route and strengthening the construction of transportation and communication, not only can we release excess capacity, but also improve the living standards of people along the line, reduce the trade costs of both sides, enhance trade facilitation, and promote trade between China and countries along the route. .

\section{The Proposed Methodology}

\subsection{The Status Quo and Characteristics of Trade Friction}

In the context of the "Belt and Road" strategy, most of the countries along the Asian region are developing countries. However, due to the economic underdevelopment and limited construction funds, infrastructure construction such as transportation and communication equipment in most developing countries needs to be developed. This has provided a broad market for China's 
electromechanical equipment, building materials industry and service industry, and China will inevitably trade friction with such industrial exporting countries as the United States in the process of seizing such markets. At the same time, the financial friction between China and the United States has become increasingly fierce. In order to promote economic integration in the Asian region, the Asian Infrastructure Investment Bank was established in 2014. The service covers 57 countries, which is partly to the Asian Development Bank headed by the United States. The threat will inevitably lead to obstruction by the United States. It can be seen that the trade friction faced by China has spread from the purely physical trade sector to the monetary and financial sector.

Stimulated by the "Belt and Road" strategy, US trade protectionism has demonstrated new features of range expansion, frequency increase, and concealment. The United States launched a series of trade remedy measures against China, ranging from high-profile steel products, tires, containers and solar photovoltaic products, to galvanized steel wire and chemical brighteners, and MSG. Only one steel product was prosecuted for 22 times. The troubles of the United States in the United States have clearly reflected the rise of internal protectionism in the United States. The United States also frequently used the more concealed "377" survey to protect domestic products as an excuse to boycott Chinese products. In February 2013, the report "Reducing the US Trade Secret Theft Strategy" pointed out that China frequently steals US corporate trade secrets and The innovative achievements of intellectual property rights will be used to combat such Chinese enterprises from various channels such as diplomacy, trade and legislation.

\subsection{The Impact of the "Belt and Road" Strategy on China's International Trade}

The countries along the "Belt and Road" have a problem of imperfect domestic infrastructure, which has also caused economic underdevelopment. Therefore, it is urgent to solve the infrastructure problem, which requires a lot of capital, talents and technology. After the reform and opening up, through years of practice and efforts, the capacity and level of China's infrastructure has been quite mature. Under the influence of the "One Belt, One Road” plan, it will bring advanced technology and resources to more countries with such needs, and promote domestic labor export, increase the export volume of infrastructure raw materials and related equipment, and develop China's foreign trade economy. Play a driving role.

"Trade facilitation" mainly refers to the simplification of trade procedures and the breaking of administrative restrictions. For international trade, it has always faced the constraints caused by the differences in political, social, economic and cultural aspects of different countries. Especially for the current economic tide, countries have adopted strategic trade protection policies to promote the health of their national industries with development, which undoubtedly led to an increase in the factors affecting the trade between China and Africa. According to the measures in the "One Belt, One Road" strategic approach, it has greatly promoted the liberalization and facilitation of trade. For example, the strategy simplifies international trade procedures such as quarantine, certification, and measurement standards, improves software and hardware performance such as customs clearance facilities, and reduces unnecessary tariff barriers, enhances trade transparency, and coordinates trade between countries along the route. The policy has directly improved the level of trade facilitation between neighboring countries and China, helped to improve China's international trade, and promoted sustained and steady growth of bilateral and multilateral trade.

\subsection{Countermeasures for Dealing with International Trade Friction}

The proposal of the "Belt and Road" strategic measures has played an important role in promoting the economic development of China and its countries along the route. On the one hand, it is conducive to the reform of the trade system of China's “One Belt, One Road” strategic region. At the same time, 
it has greatly encouraged foreign trade enterprises to expand their business, improve foreign trade and goods trade, and promote the rapid development of international trade economy. On the other hand, the rapid development of China's international trade has inevitably brought trade with other countries, increased the source of trade, and also brought about trade frictions between countries, which has led to a sharp rise in the amount of trade friction in China. Under the new situation of "One Belt, One Road”, we should calmly deal with the trade friction brought about by international trade with a proactive attitude.

China's traditional foreign trade development model no longer has advantages, and new advantages have not yet been presented. At this critical juncture, China faces the dual competitive pressures of many developed and developing countries. On the one hand, in the international market competition, in the labor-intensive industry sector, China and other developing countries compete fiercely. In the first three quarters of 2016, China's labor-intensive enterprises compared with Japan and the United States and the market share decreased by $1.5 \%$ and $2.7 \%$ respectively. At the same time, Vietnam's share in the intensive industry markets in Japan and the United States increased by $0.6 \%$ and $1.1 \%$ respectively. On the other hand, in the future development of intensive industries, there are both competitive and cooperative relationships between China and other developed countries, and the requirements of developed countries for emerging industries will be more stringent.

As the world trade protection idea gradually matures, it has increased China's negative role in the trade market. So far, China has become one of the key protection countries of the World Trade Organization. In the first half of 2016 alone, the number of trade remedy investigations initiated by China in 21 countries and regions around the world reached 95, up 45\% from the previous year. Among them, the total amount reached 11 billion US dollars, an increase of 85\% compared with the previous year. During this period, China's photovoltaic, aluminum and steel industries became major industries that caused friction with each other in the world, causing serious and adverse impacts on China's export trade.

\subsection{Under the "Belt and Road" Strategy, China's New Factors Affecting the Development of Foreign Trade}

The "Belt and Road" strategy is only a vision of foreign economic cooperation. With the implementation of this strategic concept and the cooperation and participation of countries, its connotation will be further enriched. Although the basic content of the "One Belt, One Road" strategy is economic cooperation, such large-scale economic cooperation certainly needs the support of political relations, and certainly cannot be supported by government diplomacy. The regional goal of the Silk Road Economic Belt is to achieve policy communication, road connectivity, smooth trade, currency circulation, and people-to-people communication, namely, communication and interconnection, free trade and investment, free circulation of money, and friendly exchange of people. It is inseparable from the support of the national policy of the "Belt and Road" strategic region. It can be envisaged that after the implementation of the "One Belt, One Road" strategy, countries will implement various preferential policies to support trade cooperation in the Silk Road Economic Belt, thereby promoting mutual benefit and mutual benefit of the Silk Road Economic Belt.

\section{Conclusion}

Many countries involved in the "Belt and Road" strategy are still at a low-end level. Although China's equipment and production capacity still have some problems in terms of quality and safety, it still has certain advantages in the international market due to its high cost performance. As the industry further transforms and upgrades, China's equipment, such as production lines, can better help 
strategic cooperative countries develop the real economy and advance their industrialization process. For example, at the end of 2014, China signed a cooperation agreement with Kazakhstan on the capacity of China and Kazakhstan, and China exported production line equipment to Kazakhstan. With the implementation of the "Belt and Road" strategy and the transformation and upgrading of China's industry, the position of large industrial exports in foreign trade will be more important.

\section{References}

[1] FENG, Z. and JIANG, W., 2017. Research on National Strategy of "One Belt, One Road” An IntraIndustry Trade Perspective. Journal of International Trade, 3, p.015.

[2] Munawaroh, M., Ghozali, I., Fuad, F. and Faisal, F., 2018. The Trade-off Strategy between Financial and Environmental Performance: Assessment of Sustainable Value Added. International Journal of Energy Economics and Policy, 8(1), pp.5-11.

[3] Wang, Y., Li, J. and Wang, H.H., 2017. Cluster and cloud computing framework for scientific metrology in flow control. Cluster Computing, pp.1-10.

[4] O'Connell, S. and Economy, G.P., 2018. Currency and International Trade in the Age of Globalised Production: A Quantitative Analysis (Master's thesis).

[5] Huang, W., Wang, P., Lv, L., Wang, L. and Wang, H.H., 2018. An inventive high-performance computing electronic information system for professional postgraduate training. International Journal of Computers and Applications, pp.1-7. [6] Cámara, J., Schmerl, B., Moreno, G.A. and Garlan, D., 2018. MOSAICO: offline synthesis of adaptation strategy repertoires with flexible trade-offs. Automated Software Engineering, pp.1-32. 